\title{
PENGARUH PRODUK DOMESTIK BRUTO, NILAI EKSPOR, DAN INFLASI TERHADAP INVESTASI ASING LANGSUNG DI INDONESIA PADA TAHUN 2010-2019
}

\author{
Farhah Bella Anindita \\ farhahbellanindita@yahooo.com \\ Jhonny Marbun \\ jhonnymarbun3@gmail.com \\ Agus Supriyadi \\ aguspd2@gmail.com \\ Program Studi Keuangan dan Perbankan Terapan Politeknik Negeri Jakarta
}

\begin{abstract}
Indonesia is a developing country that embraces an open economy in which to run its economy, the government will not escape the interaction of private sector or other countries. In this case, Indonesia certainly needs a large enough funding to build an equitable and prosperous economy for its people. Foreign direct investment is one of the alternative financing from abroad that can be used as additional funding for economic development in Indonesia. Foreign direct investment is influenced by several factors. This study aims to analyze the Gross Domestic Product, Export Value, and Inflation of Foreign Direct Investment in 2010-2019. The type of data used is secondary data obtained from the official website of the Central Statistics Agency, Capital Investment Coordinating Board, Ministry of Trading, and Bank Indonesia. The method of analysis which used by the research is multiple linear regression analysis with a significance level of 5\%. This study results showed that partially Gross Domestic Product has a significant positive effect on Foreign Direct Investment. Export Value has a significant negative effect on Foreign Direct Investment and Inflation has a significant positive effect on Foreign Direct Investment. Meanwhile, the variable of Gross Domestic Product, Export Value, and Inflation has a significant effect on Foreign Direct Investment by 91,2\%, while the remaining 8,8\% was needed by other factors outside of this research.
\end{abstract}

Keywords: GDP, Export Value, Inflation, Foreign Direct Investment.

\begin{abstract}
ABSTRAK
Indonesia merupakan negara berkembang yang menganut perekonomian terbuka di mana dalam menjalankan perekonomiannya, pemerintah tidak luput akan adanya interaksi dari pihak swasta ataupun negara-negara lain. Dalam hal ini, Indonesia tentu memerlukan pembiayaan yang cukup besar untuk membangun perekonomian yang merata dan sejahtera bagi rakyatnya. Investasi asing langsung merupakan salah satu alternatif pembiayaan berasal dari luar negeri yang dapat digunakan sebagai tambahan pembiayaan dalam pembangunan ekonomi di Indonesia. Investasi asing langsung dipengaruhi oleh beberapa factor. Penelitian ini bertujuan untuk menganalisis Produk Domestik Bruto, Nilai Ekspor, dan Inflasi terhadap Investasi Asing Langsung di Indonesia Tahun 2010-2019. Jenis data yang digunakan adalah data sekunder yang diperoleh dari website resmi Badan Pusat Statistik, Bank Indonesia, Kementrian Perdagangan, dan Badan Koordinasi Penanaman Modal. Metode analisis yang digunakan adalah Regresi Berganda dengan tingkat signifikansi 5\%. Hasil dari penelitian ini menunjukan bahwa secara parsial PDB berpengaruh positif signifikan terhadap Investasi Asing Langsung, Nilai Ekspor berpengaruh negatif signifikan terhadap Investasi Asing Lang sung, dan Inflasi berpengaruh positif signifikan Investasi Asing Langsung. Sedangkan secara simultan, variabel PDB, Nilai Ekspor, dan Inflasi berpengaruh signifikan terhadap Investasi Asing Langsung di Indonesia sebesar 91,2\%, sedangkan sisanya sebesar 8,8\% dipengaruhi oleh faktor lain di luar penelitian ini.
\end{abstract}

Kata kunci: PDB, Nilai Ekspor, Inflasi, Investasi Asing Langsung

\section{PENDAHULUAN}

\section{Latar Belakang}

Indonesia merupakan negara

berkembang yang menganut perekonomian

terbuka di mana dalam menjalankan perekonomiannya, pemerintah tidak luput akan adanya interaksi dari pihak swasta ataupun negara-negara lain. Dalam hal ini, Indonesia tentu memerlukan pembiayaan yang cukup besar untuk membangun perekonomian yang 
merata dan sejahtera bagi rakyatnya seperti yang ditegaskan di dalam Pembukaan UndangUndang Dasar 1945.

Saat ini, Indonesia belum mampu untuk menyediakan seluruh dana pembangunan tersebut salah satu penyebabnya adalah besarnya tabungan domestik masih kurang memenuhi investasi yang dibutuhkan. Kesenjangan antara tabungan domestik dan kebutuhan investasi (saving investment gap) yang diperlukan dalam mencapai satu tingkat pertumbuhan ekonomi tertentu, mengharuskan pemerintah untuk mencari sumber alternatif pembiayaan lain. Oleh karena itu, pemerintah selain menggali sumber pembiayaan dalam negeri juga melakukan kebijakan dalam mendapatkan sumber-sumber dana dari luar negeri, diantaranya adalah pinjaman luar negeri, penanaman modal asing, dan hibah.

Jika pemerintah suatu negara terus menerus mengandalkan utang luar negeri dalam menutupi defisit dana yang dibutuhkan dalam pembangunan, maka hal ini akan mengakibatkan penumpukan utang dalam jangka panjang dan akhirnya akan menjadi beban tersendiri yang harus ditanggung oleh negera tersebut.

Selain hutang luar negeri pemerintah dapat mengupayakan sumber dana dari luar negeri di antara lain dengan penanaman modal asing. Adanya investasi yang masuk oleh pihak asing akan mendukung pembiayaan pembangunan jangka panjang dan lebih menguntungkan apabila dibandingkan dengan pembiayaan yang bersumber dari utang luar negeri (Febriana, 2014).

Penanaman Modal Asing ialah aliran modal yang bersumber dari luar negeri yang bergerak ke sektor swasta baik melalui investasi asing langsung maupun investasi tidak langsung. Investasi asing langsung dianggap lebih bermanfaat karena adanya pengaruh yang diberikan dari investasi asing langsung betulbetul terasa yaitu transfer ilmu pengetahuan, teknologi baru, pengembangan keterampilan, penciptaan lapangan kerja, meningkatkan modal, dan pengembangan sektor industri pada host country. Investasi asing langsung juga cenderung akan menjadi pilihan yang dilakukan oleh negara yang tidak memiliki batasan dan memiliki potensi pertumbuhan ekonomi. Investasi asing langsung tersebut diperlukan untuk menutup adanya kesenjangan antara investasi dan tabungan di negara berkembang. Dibandingkan bentuk modal lainnya, investasi asing langsung merupakan aliran modal yang bersifat jangka panjang dan relatif tidak rentan terhadap gejolak perekonomian.

Pada beberapa tahun terakhir ini, Indonesia merupakan negara yang memiliki kinerja yang rendah namun memiliki potensi yang tinggi dalam pengelolaan penanaman modal asing. Oleh karena itu, untuk mendorong masuknya investasi asing langsung yang lebih besar ke Indonesia, diperlukan pengetahuan akan faktor-faktor yang mempengaruhi besarnya arus investasi asing langsung di Indonesia.

Salah satunya perkembangan ekonomi suatu negara yang diukur dengan pertumbuhan ekonomi menunjukkan pertumbuhan produksi barang dan jasa di suatu wilayah perekonomian dalam selang waktu tertentu yang biasa dikenal dengan Produk Domestik Bruto (PDB). I Made Yogatama (2011) di dalam penelitiannya menyebutkan PDB berpengaruh signifikan terhadap investasi asing langsung yang masuk kedalam perekonomian Indonesia. Sedangkan dalam penelitian John David (2013) menyatakan PDB tidak berpengaruh signifikan terhadap investasi asing langsung di Indonesia. Dalam beberapa tahun terakhir PDB Indonesia terus mengalami kenaikan.

Selain itu, dalam penambahan peningkatan penanaman modal asing untuk menambah daya tingkat investasi di suatu Negara, dalam hal ini suatu negara dikatakan aktif dalam perdagangan internasional jika nilai total ekspor lebih besar dari pada nilai total impor.

Nilai total ekspor yang terus mengalami kenaikan diyakini akan diikuti dengan naiknya jumlah investasi asing langsung yang masuk kedalam perekonomian negara tersebut. Bobby dan I Wayan (2013) di dalam penelitiannya mendapatkan hasil total ekspor berpengaruh positif dan signifikan terhadap investasi asing langsung di Indonesia. Sebaliknya, pada penelitian Hilasterion Ndruru (2019) menyatakan bahwa nilai total ekspor berpengaruh dan tidak signifikan terhadap investasi asing langsung di Indonesia.

Inflasi yang rendah akan dapat mendorong perekonomian lebih baik, yaitu meningkatkan pendapatan nasional dan membuat orang bergairah untuk bekerja, menabung dan meningkatkan investasi. Hal ini sejalan dengan penelitian Sony Hendra dan Edmira Rivani (2013) menyatakan bahwa inflasi berpengaruh positif signifikan terhadap 
investasi asing langsung di Indonesia. Namun sebaliknya pada penelitian M Fazran (2018) menyatakan bahwa berpengaruh negatif dan tidak memilikki pengaruh signifikan terhadap investasi asing langsung di Indonesia.

\section{Permasalahan}

Berdasarkan permasalahan pada latar belakang maka dapat diketahui beberapa perumusan masalah yang dapat diambil sebagai dasar kajian penelitian yang dilakukan, antara lain:

1. Apakah produk domestik bruto berpengaruh signifikan terhadap investasi asing langsung di Indonesia?

2. Apakah nilai ekspor berpengaruh signifikan terhadap investasi asing langsung di Indonesia?

3. Apakah inflasi berpengaruh signifikan terhadap investasi asing langsung di Indonesia?

4. Apakah produk domestik bruto, nilai ekspor, dan inflasi berpengaruh secara simultan terhadap investasi asing langsung di Indonesia?

\section{Tujuan}

Berdasarkan latar belakang dan rumusan masalah di atas, maka tujuan yang akan dicapai dari penelitian ini adalah:

1. Menganalisis pengaruh produk domestik bruto terhadap investasi asing langsung di Indonesia.

2. Menganalisis pengaruh nilai ekspor terhadap investasi asing langsung di Indonesia.

3. Menganalisis pengaruh inflasi terhadap investasi asing langsung di Indonesia.

4. Menganalisis apakah produk domestik bruto, nilai ekspor, dan inflasi berpengaruh secara simultan terhadap investasi asing langsung di Indonesia.

\section{TINJAUAN PUSTAKA \\ Investasi Asing Langsung}

Investasi asing langsung, merupakan penanaman modal asing yang meliputi investasi ke dalam aset-aset secara nyata berupa pembangunan pabrik-pabrik, pengadaan berbagai macam barang modal, pembelian tanah untuk keperluan produksi, dan sebagainya. Investasi asing langsung ini dianggap sebagai salah satu sumber modal pembangunan ekonomi yang penting. Semua negara yang menganut sistem ekonomi terbuka, pada umumnya memerlukan investasi asing, terutama perusahaan yang menghasilkan barang dan jasa untuk kepentingan ekspor.

Dalam upaya untuk menarik minat investor asing menanamkan modalnya di Indonesia, pemerintah terus meningkatkan kegiatan promosi, baik melalui pengiriman utusan ke luar negeri maupun peningkatan kerjasama antara pihak swasta nasional dengan swasta asing. Sementara itu, Badan Koordinasi Penanaman Modal (BKPM) sebagai badan yang bertanggung jawab dalam kegiatan penanaman modal terus mengembangkan perannya dalam menumbuhkan investasi.

\section{Teori Investasi Asing Langsung}

Moosa dalam jurnalnya Lumban raja mengemukakan bahwa terdapat lima dasar terori investasi asing langsung:

\section{The differential rate of return hypotesis}

Teori ini menjelaskan bahwa keputusan melakukan investasi asing langsung perlu memertimbangkan marginal return dan marginal costnya. Hal tersebut dikarenakan investor dalam mengalirkan modalnya harus melihat negara mana yang mampu memberikan return yang lebih tinggi dalam suatu proses yang singkat.

2. The diversivication hypotesis

Teori ini menyatakan bahwa keputusan berinvestasi tidak hanya memertimbangan return yang didapat namun juga risiko yang akan dihadapi. Berdasarkan sifatnya terhadap risiko, terdapat tiga tingkatan, diantaranya; pertama, risk averse, yaitu penghindaran risiko, investor lebih memilih proyek yang berisiko rendah meskipun cenderung akan mendapat tingkat keuntungan yang rendah juga; kedua, risk medium, yaitu (sifat proporsional) melihat risiko dengan berinvestasi pada risiko sedang pada tingkat keuntungan tertentu; ketiga, risk taker ialah sifat yang berani mengambil risiko dengan berinvestasi pada return yang besar tanpa memerdulikan konsekuensi risiko yang lebih tinggi.

\section{The output and market size hypotesis}

Pada teori ini investasi asing langsung yang masuk ke suatu negara berkaitan dengan output dari perusahaan asing tersebut, besarnya ukuran pasar dari suatu negara diukur berdasarkan Produk Domestik Brutonya. 


\section{The currency areas hypotesis}

Teori ini menggambarkan bahwa perusahaan asing yang memiliki nilai kurs (mata uang) yang lebih kuat dibandingkan negara lainya, cenderung akan berinvestasi sebab negara yang bermata uang lemah umumnya tidak mampu berinvestasi karena risiko yang mungkin dihadapinya akan tinggi.

\section{The product life cycle hypotesis}

Gambaran dari teori ini ialah barang/jasa yang dihasilkan pertama kali dianggap menjadi inovasi di negara asalnya. Lambat laun, barang/jasa tersebut akan tersebar ke beberapa negara sehingga menjadi terstandarisasi. Investasi asing langsung muncul dari reaksi- reaksi oleh perusahaan, dengan ekspansi ke luar negeri, yang memiliki kemungkinan kehilangan pasar karena produknya berkembang.

\section{Produk Domestik Bruto}

Dalam bidang ekonomi, produk domestik bruto (PDB) adalah nilai pasar semua barang dan jasa yang diproduksi oleh suatu negara pada periode tertentu. PDB merupakan salah satu metode untuk menghitung pendapatan nasional. konsep produk domestik bruto menurut Sukirno adalah "Produk domestik bruto dapat diartikan sebagai nilai barang-barang dan jasa-jasa yang diproduksikan di dalam negara dalam satu tahun tertentu".

Menurut Mankiw, komponen PDB terdiri dari beberapa komponen, yaitu :

1. Konsumsi (consumption) adalah pembelanjaan barang dan jasa oleh rumah tangga.

2. Investasi (investment) adalam pembelian barang yang nantinya akan digunakan untuk memproduksi lebih banyak barang dan jasa.

3. Belanja pemerintah (government purchases) mecakup pembelanjaan barang dan jasa oleh pemerintah daerah, negara bagian, dan pusat (federal).

4. Eskpor Neto (NX) sama dengan pembelian produk dalam negeri oleh orang asing (ekspor) dikurangi pembelian produk luar negeri oleh warga negara (impor).

\section{Perhitungan Produk Domestik Bruto}

Elvis F. Purba, Tobing dan Hutabarat, menjelaskan bahwa: "Angka produk domestik bruto dapat dihitung dengan tiga pendekatan, yaitu (1) pendekatan produksi, (2) pendekatan pengeluaran, dan (3) pendekatan pendapatan".

\section{Pendekatan Produksi}

Menurut pendekatan produksi, produk domestik bruto adalah jumlah nilai barang dan jasa akhir yang dihasilkan oleh berbagai unit produksi (sektor ekonomi atau lapangan usaha) di wilayah Indonesia dalam jangka waktu satu tahun yang datanya disajikan dalam jangka waktu tahunan, baik atas dasar harga berlaku maupun atas dasar harga konstan.

2. Pendekatan Pengeluaran

Di mana konsumsi adalah pengeluaran

$$
P D B=C+I+G+N-X
$$

yang dilakukan oleh rumah tangga, investasi oleh sektor usaha, pengeluaran pemerintah oleh pemerintah, ekspor dan impor melibatkan sektor luar negeri.

3. Pendekatan Pendapatan

Di mana sewa adalah pendapatan pemilik faktor produksi tetap seperti tanah, upah untuk tenaga kerja, bunga untuk pemilik modal, dan laba untuk pengusaha.

\section{Nilai Ekspor}

Ekspor merupakan salah satu jenis pengeluaran yang mempengaruhi besarnya Product Domestik Bruto (PDB) suatu negara. Perubahan yang terjadi pada nilai ekspor akan mempengaruhi pendapatan pemerintah berupa devisa.

Sarwedi menjelaskan bahwa, penawaran ekspor dipengaruhi oleh penanaman modal asing (PMA). Peningkatan PMA secara tidak langsung akan meningkatkan industrialisasi. Sebagai akibatnya, jumlah barang yang diproduksi akan meningkat. Hubungan yang positif ini memang masih menjadi perdebatan. Hal ini disebabkan oleh peluang terjadinya penanaman modal asing sangat tergantung dan dipengaruhi oleh kebijakan negara penerima atau host country.

Hubungan akan ekspor dengan terjadinya investasi dinyatakan juga oleh Mankiw dalam bukunya menjelaskan dengan identitas perhitungan pendapatan nasional dalam bentuk tabungan dan investasi, yaitu:

$$
\mathbf{Y}=\mathbf{C}+\mathbf{I}+\mathbf{G}+\mathbf{N X}
$$


Dimana dapat diubah menjadi,

$$
\mathbf{Y}-\mathbf{C}-\mathbf{G}=\mathbf{I}+\mathbf{N X}
$$

Dalam pendeketan tabungan maka persamaan sebelumnya dapat diubah menjadi,

$$
\mathbf{S}=\mathbf{I}+\mathbf{N X}
$$

Lalu menjadi,

$$
\mathrm{S}+\mathbf{I}=\mathbf{N X}
$$

NX merupakan ekspor neto yang terdapat dalam neraca pembayaran, sedangkan I merupakan investasi. Maka dapat diketahui besar kecilnya nilai total ekspor akan mempengaruhi akan investasi di suatu Negara.

\section{Inflasi}

Latumaerissa (2011, p. 22) mengemukakan definisi singkat dari inflasi ialah kecenderungan dari harga-harga untuk naik secara terus menerus. Selain terjadi secara terus menerus, kenaikan harga bisa disebut dengan inflasi apabila kenaikan harga tersebut mencakup keseluruhan jenis barang.

Sementara itu Bank Indonesia memberikan pengertian Inflasi yaitu meningkatnya harga-harga secara umum dan terus menerus. Kenaikan dari satu atau dua barang saja tidak dapat disebut inflasi kecuali bila kenaikan itu meluas (atau mengakibatkan kenaikan harga) pada barang lainnya. Kebalikan dari inflasi disebut deflasi (www.bi.go.id).

\section{METODE PENELITIAN}

Jenis dan sumber data yang digunakan dalam penelitian ini adalah data sekunder (time series) yang diperoleh dari beberapa lembaga dan instansi pemerintah, antara lain berasal dari Badan Pusat Statistik (BPS), Badan Koordinasi Penanaman Modal (BKPM), Kementrian Perdagangan, dan SEKI Bank Indonesia.

Populasi yang digunakan dalam penelitian ini adalah semua data perkembangan produk domestik bruto, nilai ekspor, inflasi, dan investasi asing langsung di Indonesia dari tahun 2010-2019. Sedangkan metode sampling yang digunakan dalam penelitian ini adalah purposive sampling.

Variabel dependen dalam penelitian ini adalah investasi asing langsung, sedangkan variabel independennya adalah produk domestik bruto, nilai ekspor, dan inflasi.
Analisis data yang digunakan adalah analisis regresi linear berganda yang selanjutnya dilakukan juga uji asumsi klasik yakni uji multikolinearitas, uji autokorelasi, uji heteroskedastisitas, dan uji normalitas. Untuk uji signifikansi digunakan uji t (parsial) dan uji F (simultan). Kemudian dilakukan uji koefisien determinasi untuk mengetahui besar pengaruh variabel $\mathrm{X}$ terhadap variabel $\mathrm{Y}$.

\section{HASIL DAN PEMBAHASAN

\begin{tabular}{|c|c|c|}
\hline \multirow[t]{2}{*}{ Model } & \multicolumn{2}{|c|}{$\begin{array}{c}\text { Unstandardized } \\
\text { Coefficients }\end{array}$} \\
\hline & $\mathrm{B}$ & Std. Error \\
\hline (Constant) & $-21,703$ & 2,584 \\
\hline PDB & 2,429 & ,136 \\
\hline Nilai Ekspor &,- 376 &, 156 \\
\hline Inflasi &, 030 &, 012 \\
\hline
\end{tabular} \\ Analisis Regresi Linear Berganda}

Tabel 1 Hasil Uji Regresi Linier Berganda

Berdasarkan tabel diatas maka dapat diperoleh persamaan sebagai berikut: $Y=-21,703+2,429 X 1-0,376 X 2+0,30 X 3$ Keterangan:

1. Nilai konstanta merupakan besarnya nilai variabel dependen ( $\mathrm{Y}$ ) tanpa adanya perngaruh variabel independen (X). Nilai konstanta artinya Investasi Asing Langsung tanpa adanya pengaruh dari Produk Domestik Bruto (X1), Nilai Ekspor (X2), dan Inflasi (X3) adalah sebesar $-21,703$ Triliun Rp.

2. Variabel Produk Domestik Bruto mempunyai koefisien regresi bertanda positif terhadap Investasi Asing Langsung dengan nilai koefisien sebesar 2,429. Artinya, apabila Produk Domestik Bruto terjadi kenaikan sebesar satu persen, maka Investasi Asing Langsung akan meningkat sebesar 2,429 Triliun Rp dengan asumsi variabel lain dianggap konstan.

3. Variabel Nilai Ekspor mempunyai koefisien regresi bertanda negatif terhadap Investasi Asing Langsung dengan nilai koefisien sebesar - 0,376. Artinya, setiap terjadi kenaikan Nilai Ekspor sebesar satu persen, maka akan menyebabkan penurunan Investasi Asing Langsung sebesar 0,376 Triliun Rp dengan asumsi variabel lain dianggap konstan. 
4. Variabel Inflasi mempunyai nilai koefisien regresi bertanda positif terhadap Investasi Asing Langsung dengan nilai koefisien sebesar 0,30. Artinya, setiap terjadi kenaikan Inflasi sebesar satu persen, maka akan menyebabkan meningkatnya persentase Investasi Asing Langsung Triliun Rp 0,30 persen dengan asumsi variabel lain dianggap konstan.

\section{Uji t (Parsial)}

Tabel 2 Hasil Uji t

\begin{tabular}{|c|c|c|c|}
\hline \multicolumn{4}{|c|}{ Uji T (parsial) } \\
\hline Variabel & Nilai Sig. & $\begin{array}{c}\text { Nilai t- } \\
\text { tabel }\end{array}$ & Hasil \\
\hline PDB & $0,000<$ & $17,894>$ & H1 \\
(X1) & 0,05 & 2,029 & diterima \\
\hline Ekspor & $0,021<$ & $-2,404>$ & H2 \\
(X2) & 0,05 & 2,029 & diterima \\
\hline Inflasi & $0,018<$ & $2,477>$ & H3 \\
(X3) & 0,05 & 2,029 & diterima \\
\hline
\end{tabular}

Sumber: Hasil Output SPSS Versi 26

Variabel Produk Domestik Bruto memiliki nilai signifikansi sebesar 0,000 dan nilai t-hitung sebesar 17,894 lebih besar dari ttabel sebesar 2,029 sehingga $\mathrm{H}_{1}$ diterima. Variabel Nilai Ekspor memiliki nilai signifikansi sebesar 0,021 dan nilai t-hitung sebesar -2,404 lebih besar dari t-tabel sebesar 2,029 sehingga $\mathrm{H}_{2}$ diterima. Variabel Inflasi memiliki nilai signifikansi 0,018 dan nilai thitung sebesar 2,477 lebih besar dari t- tabel sebesar 2,029 dan hasilnya menunjukkan $\mathrm{H}_{3}$ diterima.

Uji F (Simultan)

Tabel 3 Hasil Uji F

\begin{tabular}{|c|c|c|c|}
\hline \multicolumn{4}{|c|}{ Uji F (parsial) } \\
\cline { 1 - 1 } Variabel & Nilai Sig. & $\begin{array}{c}\text { Nilai f- } \\
\text { tabel }\end{array}$ & Hasil \\
\cline { 1 - 2 } PDB & & & \\
(X1) & & & \\
\cline { 1 - 1 } Ekspor & $0,000>$ & $135,838>$ & H4 \\
(X2) & 0,05 & 2,86 & diterima \\
\cline { 1 - 1 } Inflasi & & & \\
(X3) & & & \\
\hline
\end{tabular}

Sumber: Hasil Output SPSS Versi 26

Variabel Produk Domestik Bruto, Nilai Eskpor, dan Inflasi secara simultan atau bersama-sama mempengaruhi variabel Investasi Asing Langsung dengan nilai signifikansi sebesar 0,000 dan nilai f-tabel 135,838 sehingga $\mathrm{H}_{4}$ diterima.

\section{Uji Koefisien Determinasi}

Tabel 4 Hasil Uji Koefisien Determinasi

\begin{tabular}{|r|c|r|r|r|}
\hline \multicolumn{5}{|c|}{ Model Summary } \\
\hline & & \multicolumn{1}{c|}{ R } & Adjusted & Std. Error of \\
Model & R & Square & R Square & the Estimate \\
\hline &, $959^{\mathrm{a}}$ &, 919 &, 912 &, 11094 \\
\hline
\end{tabular}

Sumber: Hasil Output SPSS Versi 26

Berdasarkan tabel diatas dapat diketahui bahwa nilai adj. R Square adalah sebesar 0,912. Hal ini menunjukkan bahwa besarnya presentase Produk Domestik Bruto, Nilai Ekspor, dan Inflasi berpengaruh secara simultan sebesar $91,2 \%$ sedangkan sisanya sebesar $8,8 \%$ dijelaskan oleh variabel lain yang di tidak diajukan dalam penelitian ini.

\section{Uji Asumsi Klasik \\ 1. Uji Multikolineritas}

Tabel 5 Hasil Uji Multikolinearitas

\begin{tabular}{|c|c|c|}
\hline \multirow{2}{*}{ Model } & \multicolumn{2}{|c|}{ Collinearity Statistics } \\
\cline { 2 - 3 } & Tolerance & VIF \\
\hline PDB &, 749 & 1,336 \\
\hline Nilai Eskpor &, 950 & 1,053 \\
\hline Inflasi &, 775 & 1,291 \\
\hline
\end{tabular}

Sumber: Hasil Output SPSS Versi 26

Dari tabel di atas dapat dilihat berdasarkan hasil pengolahan data pada SPSS bahwa nilai VIF dari masing-masing variabel independen menunjukkan angka yang berada di bawah 10 yaitu pada variabel Produk Domestik Bruto sebesar 1,336, variabel Nilai Eskpor sebesar 1,053 dan variabel Inflasi sebesar 1,291. Pada nilai tolerance masing-masing variabel menunjukkan angka yang lebih besar dari 0,10 yaitu pada variabel Produk Domestik Bruto sebesar 0,749, variabel Nilai Ekspor sebesar 0,950 dan variabel Inflasi sebesar 0,775. Berdasarkan tabel tersebut dapat disimpulkan bahwa tidak ada gejala multikolinieritas antar variabel independen dalam penelitian ini.

\section{Uji Autokorelasi}

Tabel 6 Hasil Uji Autokorelasi

\begin{tabular}{|c|c|}
\hline \multicolumn{2}{|c|}{ Model Summary } \\
\hline Model & Durbin-Watson \\
\hline 1 &, 615 \\
\hline
\end{tabular}

Sumber: Hasil Output SPSS Versi 26 
Berdasarkan tabel di atas dapat diketahui bahwa nilai Durbin- Watson sebesar 0,615 yang artinya berada di antara -2 dan 2, maka dapat dikatakan bahwa dalam penelitan ini tidak terjadi masalah autokorelasi.

\section{Uji Heterokedastisitas}

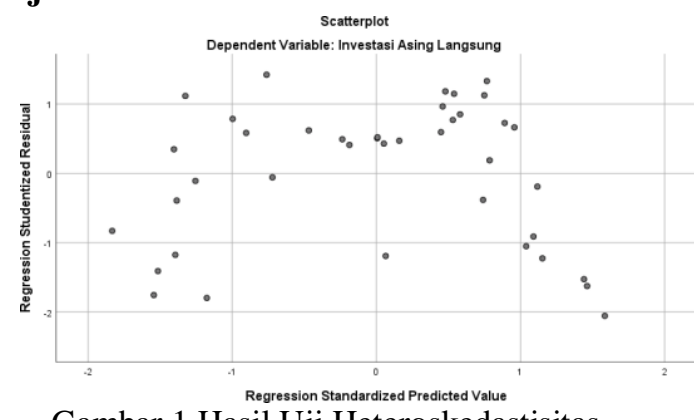

Gambar 1 Hasil Uji Heteroskedastisitas Sumber: Hasil Output SPSS Versi 26

Dari grafik scatterplot diatas, maka terlihat bahwa titik-titik tersebut menyebar diatas dan dibawah angka 0 dan titik-titik tersebut tidak mengumpul pada satu angka saja. Sehingga dapat disimpulkan bahwa tidak terjadi gejala heteroskedastisitas pada penelitian ini.

\section{Uji Normalitas}

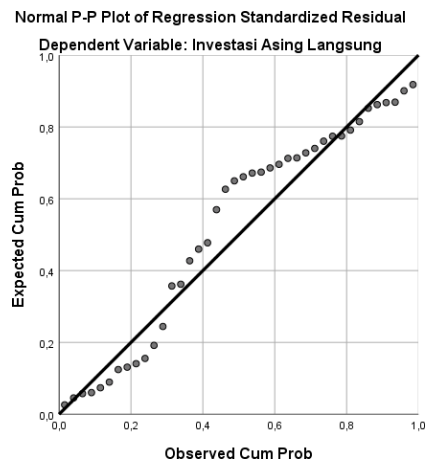

Gambar 2 Hasil Uji Normalitas

Sumber: Hasil Output SPSS Versi 26

\section{KESIMPULAN}

Berdasarkan penelitiaan yang telah dilakukan mengenai pengaruh Produk Domestik Bruto, Nilai Ekspor, dan Inflasi terhadap Investasi Asing Langsung, maka dapat disimpulkan bahwa:

1. Produk Domestik Bruto secara parsial berpengaruh positif signifikan terhadap Investasi Asing Langsung. Hubungan positif antara Produk Domestik Bruto dan Investasi Asing Langsung menunjukkan bahwa semakin meningkatnya Produk Domestik Bruto maka akan meningkatkan Investasi Asing Langsung. Hal ini terjadi karena peningkatan Produk Domestik Bruto yang berupa stabilnya pertumbuhan ekonomi negara merupakan salah satu faktor yang dapat meningkatkan Investasi Asing Langsung.

2. Nilai Ekspor secara parsial berpengaruh negatif signifikan terhadap Investasi Asing Langsung. Hubungan negatif antara Nilai Ekspor dan Investasi Asing Langsung menunjukkan bahwa semakin tinggi Nilai Eskpor maka akan menurunkan Investasi Asing Langsung. Hal ini disebabkan sebagian besar Nilai Eskpor digunakan untuk membiayai keperluan impor barang modal dan perantaraan untuk kegunaan aktivitas ekonomi domestik.

3. Inflasi secara parsial berpengaruh positif signifikan terhadap Investasi Asing Langsung. Hal ini disebabkan karena inflasi tidak berpengaruh secara langsung dalam meningkatkan minat investor dalam melakukan Investasi Asing Langsung.

4. Produk Domestik Bruto, Nilai Ekspor, dan Inflasi secara simultan berpengaruh signifikan terhadap Investasi Asing Langsung. Berdasarkan hasil uji koefisien determinasi yang dilakukan dalam penelian ini, tingkat kemampuan variabel Produk Domestik Bruto, Nilai Ekspor, dan Inflasi dalam mempengaruhi Investasi Asing Langsung sebesar 91,2\%. Artinya besaran pengaruh dari keseluruhan variabel independen yaitu Produk Domestik Bruto, Nilai Ekspor, dan Inflasi sebesar sebesar $91,2 \%$ yang mempengaruhi variabel dependen yaitu Investasi Asing Langsung.

\section{KETERBATASAN}

1. Penelitian ini hanya menggunakan beberapa variabel yang termasuk dalam faktor-faktor yang mempengaruhi investasi asing langsung yaitu produk domestik bruto, nilai eskpor, dan inflasi.

2. Data dalam penelitian hanya mewakili semua perkembangan dalam kurun waktu 10 tahun terakhir saja.

\section{DAFTAR PUSTAKA}

I Made Yogatama. (2011). Pengaruh Produk Domestik Bruto, Suku Bunga, Upah Pekerja, dan Nilai Total Ekspor Terhadap Investasi Asing Langsung di Indonesia (1990-2009). Skripsi. FE. Ilmu Ekonomi Studi Pembangunan. Universitas Diponegoro. Semarang. 
Astiti Swanitarini. (2016). Analisis FaktorFaktor yang Mempengaruhi Investasi Asing Langsung di Indonesia Tahun 2011-2014. Skripsi. FE. Pendidikan Ekonomi. Universitas Negeri Yogyakarta. Yogyakarta.

Hilasterion Ndruru. (2019). Analisis Pengaruh Produk Domestik Bruto, Suku Bunga, Upah Pekerja, dan Nilai Total Ekspor Terhadap Investasi Asing Langsung di Indonesia Tahun 2004-2017. Skripsi. FE. Ekonomi Pembangunan. Universitas HKBP Nommensen. Medan.

John David. (2013). Analisis Pengaruh PDB, Inflasi, Suku Bunga, dan Krisis Moneter Terhadap FDI di Indonesia Tahun 1981-2012. Skripsi. FE. Ilmu Ekonomi Studi Pembangunan. Universitas Diponegoro. Semarang.

Bobby Kresna Dewata \& I Wayan Yogi. (2013). Pengaruh Total Ekspor, LIBOR, dan Upah Tenaga Kerja Terhadap Investasi Asing Langsung di Indonesia. E-Jurnal Ekonomi
Pembangunan Universitas Udayana Vol.2, No. 8, 350-358.

Sony Hendra \& Edmira Rivani. (2013). Pengaruh Produk Domestik Bruto, Inflasi, Infrastruktur, dan Risiko Politik Terhadap Investasi Asing Langsung di Indonesia. Jurnal Ekonomi \& Kebijakan Publik Vol.4, No. 1, 75-87.

M Fazran Dwiputra. (2018). Analisis Pengaruh Suku Bunga Kredit dan Inflasi Terhadap Investasi Asing Langsung di Indonesia. Skripsi. FE. Ekonomi Pembangunan. Universitas Sriwijaya. Palembang.

Asri Febriana \& Masyhudi Muqorobbin. (2014). Investasi Asing Langsung di Indonesia dan Faktor Faktor yang Mempengaruhinya. Jurnal Ekonomi dan Studi Pembangunan Vol.15, No. 2, 109-117. 